Acta Biologica Plantarum Agriensis 5(1): 55 (2017) ISSN 2061-6716 (Print), 2063-6725 (Online) http://abpa.ektf.hu/
DOI:10.21406/abpa.2017.5.1.55

$4^{\text {th }}$ CC 2017 Abstract

Poster

\title{
DISTRIBUTION AND HABITAT PREFERENCE OF LEUCOBRYUM HAMPE SPECIES IN THE MECSEK MTS. (HUNGARY)
}

A Leucobryum Hampe fajok elterjedése és élőhelyi preferenciája a Mecsekben

\author{
Katalin NAGY, Judit DEME \& János CSIKY
}

University of Pécs, Faculty of Sciences, Institute of Biology, Department of Ecology, H-7624 Pécs, Ifjúság u. 6., Hungary; e-mail: moon@gamma.ttk.pte.hu

The genus Leucobryum includes two species (Leucobryum glaucum and $L$. juniperoideum) in Hungary. While L. glaucum is sparse, L. juniperoideum is rather rare in the country. The first species is protected by law in Hungary and listed in Annex V of the Habitats Directive, therefore its monitoring is obligate for all members of the EU. Because these taxa are very similar and usually occur together, it is possible to confuse them in the field.

During systematic surveys from 2016 to 2017, we have checked previously known localities and similar habitats in the Mecsek Mts. Following the standard protocol, 11 representative stands were sampled thoroughly in 1 ha quadrats. Within these quadrats five phytocoenological relevés were taken randomly in $100 \mathrm{~m}^{2}$ plots. The cover of Leucobryum $\left[\mathrm{dm}^{2}\right]$ was recorded and the presence of co-occurring species per layer were listed in the 1 ha quadrats. The cover values of moss layer, bare surfaces and organic debris were estimated within the $100 \mathrm{~m}^{2}$ plots, while the exposure, the inclination and the distance from water sources were recorded in both scale. Soil $\mathrm{pH}_{[\mathrm{H} 2 \mathrm{O}]}$ of the upper $5 \mathrm{~cm}$ layer of the ground were measured by Hannah Combo $\mathrm{pH}$ and EC meter.

43 Leucobryum stands were found in 11 flora mapping units (ca. $35 \mathrm{~km}^{2}$ ) in the Mecsek Mts. In 10 of these quadrats L. glaucum, and in 3 of them L. juniperoideum were recorded. The total cover of Leucobryum in the Mecsek is $20.500 \mathrm{~m}^{2}$ as a minimum. Considering that the last survey estimated $16.300 \mathrm{~m}^{2}$ as a minimum and $36.675 \mathrm{~m}^{2}$ as a maximum in the whole country, and there are several large white moss stands in other parts of Hungary, the results indicate the bias of the former surveys. Both species occurred on steep north-facing slopes in stands of acidophytic beech and oak forests. The average $\mathrm{pH}$ was 4.3 in the soil. Both the cover of Leucobryum and the frequency of bryophyte species, which prefer moist habitats, tend to be lower Eastwards in the Mecsek. According to the survey 129 vascular plant and 84 bryophyte species were found in the Leucobryum stands (approx. 30\% of the total bryophyte flora of the Mecsek Mts). Most of the taxa are relatively frequent in fresh acidophytic habitats, but among the bryophytes there are several threatened species (e.g. EN: Buxbaumia viridis, Jungermannia leiantha, Marsupella funckii; VU: Buxbaumia aphylla, Scapania nemorea; DD: Campylopus pyriformis; NT: Bazzania trilobata, Calypogeia fissa, Diphyscium foliosum). Although there are several large stands of white moss in the Mecsek Mts., most of them (60\%) are threatened by the expansion of Campylopus flexuosus, a strong competitor in mesic acidophytic forests. However, their habitat preference is +/different, Campylopus introflexus (probably the most dangerous invasive bryophyte species in Europe) was also found in some stands of Leucobryum (26\%).

Since the expansion or invasion of these mosses is rather fast, monitoring of Leucobryum stands in the Mecsek Mts, is the problem of the present day. 